\title{
Analisis Pengaruh Pertumbuhan Ekonomi, IPM, Pengangguran Terbuka dan Angkatan Kerja Terhadap Kemiskinan di Sumatera Utara
}

\author{
Febriangga Sembiring ${ }^{1 *}$ Tarmizi $^{2}$, Rujiman $^{3}$ \\ ${ }^{1}$ Perencanaan Wilayah Pedesaan, Sekolah PascaSarjana, Universitas Sumatera Utara \\ ${ }^{2,3}$ Fakultas Ekonomi, Universitas Sumatera Utara \\ *Koresponden email: febrianggasembiring @gmail.com@gmail.com
}

Diterima : 12 Februari 2020

Disetujui: 2 Maret 2020

\begin{abstract}
Poverty complexity problem is a multidimensional problem, and poverty is related to various aspects of people's lives so that efforts to solve the poverty problem are not easy. This study has purpose to determine and analyze Economic accretion effect, Human development index, Open Unemployment Rate, and Labor Force Participation Rate on Poverty in North Sumatra Province. Secondary data from 2004 - 2017 is used. Data Source is from Board of Central Statistics in North Sumatra Province with testing conducted through the classic judgement exam and statistical exam. With assist of EViews 6.0 statistical data data processing software, data analysis showed that Economic Accretion and idleness Rate variables have a positive and prominent influence on $\alpha=10 \%$, the Human development index variable and the Labor Force Participation Rate are not prominent at $\alpha=10 \%$, on poverty. Regression results are $\mathrm{R}^{2}=0.945055$, that shows independent variable used affects dependent variable by $94.51 \%$ and the rest $5.49 \%$ is affected by other variables beyond analyzed approach.
\end{abstract}

Keywords: Poverty, Economic Growth, Open Unemployment Rate, Labor Force Participation Rate

\begin{abstract}
Abstrak
Kompleksnya masalah kemiskinan merupakan problematika yang bersifat universal, kemiskinan berhubungan dengan berbagai bagian kehidupan sehari-hari sehingga usaha dalam menyelesaikan masalah kemiskinan cukup rumit. Riset ini bertujuan untuk menyelidiki dan menganalisis efek pengaruh Kemajuan Ekonomi, Indeks Perkembangan Manusia, Tingkat tunakarya Terbuka dan level Partisipasi Angkatan Kerja atas Kemiskinan di Sumatera Utara. Data yang dipakai merupakan data sekunder yang dikumpulkan dari 2004 - 2017 di Propinsi Sumatera Utara. Data yang dikumpulkan dari Badan Pusat Statistik Sumatera Utara di tes dengan tes asumsi klasik dan tes statistik. Perangkat lunak pengolahan data EViews 6.0 digunakan dalam analisis ini, Analisis data menampilkan variabel Perkembangan Ekonomi dan Tingkat Tunakarya Terbuka memberikan efek positif dan nyata pada $\alpha=10 \%$, variabel Indeks Perkembangan Manusia dan Level Partisipasi Angkatan Kerja tidak signifikan pada $\alpha=10 \%$, terhadap kemiskinan di provinsi Sumatera Utara. Regresi model menghasilkan $\mathrm{R}^{2}=0.945055$, yang memberikan informasi bahwa variabel bebas yang dipakai berefek pada variabel terikatnya sebesar $94,51 \%$ dan selebihnya sebesar 5,49\% dipengaruhi variabel lain yang tidak dimasukkan ke dalam model yang dianalisis.
\end{abstract}

Kata Kunci: Kemiskinan, Pertumbuhan Ekonomi, Tingkat Pengangguran Terbuka, Tingkat Partisipasi Angkatan Kerja

\footnotetext{
1. Pendahuluan

Kompleksnya masalah kemiskinan merupakan masalah yang bersifat universal, kemiskinan berhubungan dengan banyak bagian kehidupan sehingga usaha dalam memecahkan persoalan kemiskinan menjadi sulit [1]. Banyak faktor yang asumsikan berefek kuat atas masalah kemiskinan, beberapa persoalan itu meliputi keadaan perekonomian yang dikalkulasi dari kemajuan perkembangan ekonomi yang semakin naik dan level kesejahteraan masyarakat yang kalkulasi dari Human development index (HDI) atau Indeks Perkembangan Manusia (IPM). Secara teori, apabila perkembangan ekonomi dan Indeks perkembangan Manusia (IPM) naik maka tingkat kemiskinan akan turun, dan sebaliknya [2].

Kemiskinan adalah kondisi yang melibatkan berbagai aspek karena berhubungan dengan pemasukan/pendapatan yang rendah, buta huruf, derajat kesehatan yang buruk dan ketidaksamaan gender serta jeleknya lingkungan hidup. Menangani kasus kemiskinan tidak boleh dilaksanakan secara
} 
parsial/terpisah dari masalah-masalah pengangguran, pendidikan, kesehatan dan kasus lain yang secara nyata berhubungan langsung dengan masalah kemiskinan [3].

Penelitian bertujuan menyelidiki pengaruh Perkembangan Ekonomi, Indeks Pembangunan Manusia, Level Tunakarya Terbuka dan Level Partisipasi Angkatan Kerja atas Kemiskinan di Provinsi Sumatera Utara.

\section{Tinjauan Pustaka}

Hasil penelitian [4] menyatakan bahwa perbedaan signifikan dalam perubahan kemiskinan, perkembangan ekonomi, dan variabel-variabel lokal. Analisisi pada ekonometrika menampilkan diluar perkembangan ekonomi, ada hal lain yang memberikan pengaruh langsung atas kesejahteraan masyarakat miskin diluar dari efeknya terhadap pertumbuhan itu sendiri. Beberapa diantaranya adalah struktur dan infrastruktur, sumber daya manusia, subsidi harga pertanian, dan penetrasi teknologi.

Dalam penelitiannya mengenai faktor-faktor yang mempengaruhi indeks perkembangan manusia/IPM (human development index = HDI), menampilkan bahwa tidak semua variabel penjelas (independent variables) berakibat nyata atas Indeks Perkembangan Manusia (IPM). Hanya variabel perkembangan perekonomian (GDP), penanaman modal domestik bruto (GDI) dan jumlah penduduk miskin (POV) yang signifikan, di luar variabel yag tidak penting. Namun model pendekatan ini juga mempunyai kelemahan yaitu menginput variabel penjelas tingkat taraf mkemampuan membaca, karena variabel tersebut adalah bagian dari IPM. Selain itu, variabel GDP dan GDI sebaiknya dikeluarkan karena GDI merupakan komponen dari GDP (kekeliruan perkiraan karena multikolinearitas) [5].

Pengaruh Pertumbuhan Ekonomi Terhadap Kemiskinan

Pertumbuhan ekonomi adalah kondisi mutlak (a must condition) bagi penurunan tingkat kemiskinan. Kondisi idealnya adalah pertumbuhan tersebut mampu mengurangi kemiskinan. Dengan kata lain, pertumbuhan harus menyeluruh di setiap kelompok, juga termasuk di kelompok penduduk miskin. Bagian ini secara langsung memiliki arti yaitu pertumbuhan harus dipastikan terjadi di partisi-partisi dimana penduduk miskin bekerja seperti di pertanian atau sektor padat karya. Secara tidak langsung, ini juga berarti dibutuhkan pemerintah yang gesit dalam meratakan manfaat pertumbuhan yang mungkin diperoleh dari sektor canggih seperti jasa dan dan pabrik yang padat modal [6].

\section{Pengaruh IPM Terhadap Kemiskinan}

Pemerintah memegang peranan penting terutama dalam memaksimalkan peningkatan modal manusia (human capital) dan menstimulasi riset dan pemajuan dalam mengangkat produktifitas manusia yang adalah merupakan teori pertumbuhan ekonomi baru. Dalam kehidupan nyata dapat salsolam nahwa dengan melakukan penanaman modal dalam pendidikan akan dapat mengangkat kualitas sumber daya manusia yang ditunjukkan dengan meningkatnya pengetahuan dan keterampilan masyarakat. Semakin baik level edukasi bisa dipastikan pengetahuan dan keahlian juga akan naik dan akan menciptakan produktifitas kerjanya yang baik. Di bagian tidak resmi seperti pertanian, penambahan keterampilan dan keahlian tenaga kerja akan dapat memajukan hasil pertanian, karena tenaga kerja yang terampil dapat bekerja lebih baik dimana seseorang dengan produktifitas tinggi akan mendapatkan kesejahteraan lebih baik pada akhirnya, hal ini dapat dilihat dengan bertambahnya pemasukan dan konsumsinya. Rendahnya kinerja masyarakat miskin mungkin dikarenakan oleh susahnya bagi mereka dalam mendapatkan pendidikan yang layak. [7].

\section{Pengaruh Pengangguran dan Partisipasi Angkatan Kerja Terhadap Kemiskinan}

Sadono Sukirno menyebutkan bahwa pengaruh jelek dari tunakarya/pengangguran yaitu dapat membuat pemasukan masyarakat menjadi kurang dan dapat mengurangi level kesejahteraan yang telah diperoleh pada akhirnya. Menurunnya kemakmuran masyarakat karena pengangguran dapat dipastikan bisa menaikkan peluang terjebak pada masalah kemiskinan karena tidak adanya pemasukan. Bila pengangguran dalam sebuah sangat buruk, ketidaknyamanan politik dan sosial selalu muncul dan mengakibatkan pengaruh buruk bagi kemakmuran masyarakat dan peningkatan ekonomi dalam jangka Panjang [8].

Ref [9] mengemukakan pendapat yaitu ada hubungan intim sekali antara tingginya level pengangguran dan kemiskinan. Untuk masyarakat dalam kelompok besar, yang tidak memiliki akses pekerjaan tetap atau hanya paruh-waktu, mereka akan selalu berada dalam bagian masyarakat yang sangat miskin. 


\title{
3. Metode Penelitian
}

Lokasi penelitian dilaksanakan di wilayah administratif Pemerintah Provinsi Sumatera Utara, dimana jenis penelitian ini adalah penelitian kuantitatif ( [10] dalam [11]) dan data sekunder adalah sumber data yang akan diolah dalam riset ini. Data sekunder adalah data yang dikeluarkan dan dipakai oleh kelompok yang bukan pengelolanya [12]. Adapun definisi lain data sekunder adalah data yang dihimpun oleh lembaga penghimpun data dan diterbitkan kepada publik pemakai data [13]. Data yang digunakan dalam riset ini adalah dari Badan Pusat Stastistik Propinsi Sumatera Utara dalam beberapa variasi publikasi yaitu dokumen yang berisi data yang mencakup data-data Provinsi Sumatera Utara selama Tahun 2004-2017 [14].

Model yang dipakai adalah adaptasi dan modifikasi dari sejumlah riset sebelumnya [15]. Pembentukan model dilakukan dengan beberapa adaptasi yang dirasa perlu dan akan memberikan hasil yang lebih baik dalam memaparkan aspek-aspek vital persentase masyarakat miskin di Sumatera Utara. Model yang dibangun merupakan suatu model matematis pada persamaan 1 [16]:

$$
P O V=f(E G, H D I, T P T, T P A K)
$$

Dari model diatas bisa diubah ke model linear dengan aturan model pada persamaan 2:

$$
P O V_{i}=\alpha 0+\alpha 1 E G_{i}+\alpha 2 H D I_{i}+\alpha 3 T P T_{i}+\alpha 4 T P A K_{i}+\varepsilon_{i}
$$

$\begin{array}{ll}\underset{\operatorname{dimana}}{\mathrm{POV}_{\mathrm{i}}} & = \\ \mathrm{EG}_{\mathrm{i}} & = \\ \mathrm{HDI}_{\mathrm{i}} & = \\ \mathrm{TPT}_{\mathrm{i}} & = \\ \mathrm{TPAK}_{\mathrm{i}} & = \\ \varepsilon_{\mathrm{i}} & =\end{array}$

\author{
Persentase Penduduk Miskin, di Sumatera Utara dalam persen. \\ Pertumbuhan Ekonomi dalam persen. \\ Indeks Pembangunan Manusia dalam persen. \\ Tingkat Tunakarya/Pengangguran Terbuka dalam persen. \\ Tingkat Partisipasi Angkatan Kerja dalam persen. \\ Error Term
}

\section{Metode Analisis}

Tes Regresi dengan meode OLS menghendaki adanya asumsi kenormalan pada kesalahan pengganggunya. Jika asumsi kenormalan ini dilanggar, metode OLS tidak dapat digunakan untuk melakukan pendugaan.

$\mathrm{H}_{0}$ : data mengikuti sebaran normal

$\mathrm{H}_{\mathrm{a}}$ : data tidak mengikuti sebaran normal

Untuk mengetahui apakah kesalahan pengganggu berdistribusi normal, nilai Jacque Berra (JB) dari hasil uji kenormalan pengusik dikomparasi terhadap nilai Tabel Chi-Square dengan derajat bebas 2 dalam level signifikansi tertentu. Model dinyatakan lolos dari ketidaknormalan distribusi unsure pengusik jika nilai JB < nilai kritis Tabel $\chi 2$ [17] [18].

\section{Uji Multikolinearitas}

Multikolinearitas adalahmunculnya relasi linier sempurna antara variabel bebas dari sebuah model regresi. Multikolinearitas terjadi bisa dikarenakan diantaranya metode penghimpunan data yang dipakai menghalangi nilai dari variabel regressor, permasalahan model pada populasi yang diobservasi, detail model yang dipakai, pemilihan jumlah variabel bebas yang lebih banyak dari jumlah pemantauan, dan pengumpulan data gugus berkala (time series).

Pendekatan yang digunakan untuk memeriksa munculnya multikolinieritas adalah melihat nilai variance inflating factor (VIF) pada persamaan 3:

$$
V I F=\frac{1}{1-r_{12}^{2}}
$$

dimana:

$r_{12}^{2}=$ koefisien hubungan $\mathrm{X}_{1}$ dan $\mathrm{X}_{2}$

VIF menampilkan jenis yang diprediksi naik karena munculnya multikolinearitas. Jenis koefisien model regresi yang secara langsung cocok dengan VIF. Opposite/invers atau kebalikan dari VIF adalah tolerance (TOL), seperti pada persamaan 4:

$$
T O L=\frac{1}{V I F}=1-R_{j}^{2}
$$




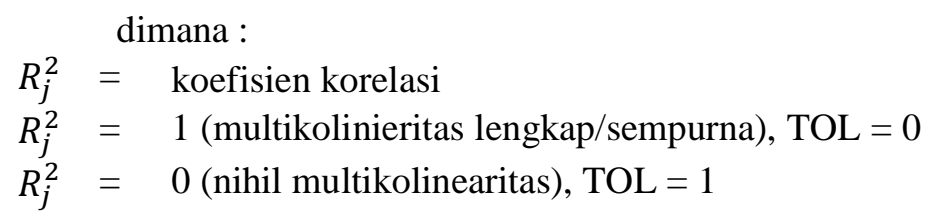

Nilai VIF yang semakin tinggi membuktikan adanya masalah multikolinearitas yang akan semakin serius jika tidak dilakukan apapun. Aturan yang dipakai adalah jika VIF $>10$ dan $R_{j}^{2}>0,90$ maka variabel itu mempunyai kolinearitas tinggi.

\section{Uji Autokorelasi}

Autokorelasi dimaksudkan sebagai hubungan/korelasi antara anggota-anggota dalam pengamatan dalam himpunan beberapa selang/deret waktu (serial correlation) atau antara anggota pengamatan bermacam entitas atau ruang (spatial correlation). Autokorelasi dapat dikarenakan aspek keterlambatan data ekonomi, bias aturan yang mengeluarkan variabel yang cocok dari model, bias aturan bentuk fungsional, kurun waktu atau lag, rekayasa data, perubahan data, dan non-stasioneritas dalam model. Metode Pendekatan yang dipakai untuk memeriksa autokorelasi dilaksanakan dengan cara uji LM/ LM Test [19]

\section{Uji Statistik}

Uji F dipakai dalam pengujian apakah ada pengaruh variabel bebas/independent secara serempak atas variabel terikat/dependent. Pengujian memiliki dasar pemikiran terhadap hipotesis nol $\left(\mathrm{H}_{\mathrm{o}}\right)$ yang akan diuji, yakni apakah semua parameter dalam model pendekatan $=0$ atau $\mathrm{H}_{\mathrm{o}}: \alpha_{1}=\alpha_{2}=\ldots=\alpha_{\mathrm{n}}=0$, pengujian ini memberikan informasi apakah seluruh variabel bebas adalah tidak merupakan penjelas yang nyata atas variabel terikat. Dan untuk $\mathrm{H}_{\mathrm{a}}$ : minimal 1 dari $\alpha_{\mathrm{n}} \neq 0$.

Untuk melakukan pengujian terhadap kedua hipotesis tersebut dilakukan dengan cara melakukan perbandingan nilai F-hitung dengan nilai F-tabel. Kalau dalam perbandingan, nilai F-hitung > F-tabel maka ini memberikan informasi yaitu seluruh variabel terikat serempak memberikan pengaruh pada variabel terikat.

Pengujian dilakukan untuk melihat kemungkinan munculnya efek dari masing-masing variabel bebas atas variabel terikat. Dasar tes statistik t adalah untuk menguji seberapa kuat efek satu variabel bebas dalam menjelaskan ragam variabel terikat. Pengujian Hipotesis nol $\left(\mathrm{H}_{\mathrm{o}}\right)$ akan memberikan informasi apakah parameter $\left(\alpha_{1}\right)=0$, atau $\mathrm{H}_{\mathrm{o}}: \alpha_{1}=0$, ini menjelaskan bahwa suatu variabel bebas tidak merupakan penjelas yang nyata atas variabel bebas. Hipotesis parameter lainnya $\left(\mathrm{H}_{\mathrm{a}}\right)$ menjelaskan bahwa jika parameter suatu variabel $\neq 0$, atau $\mathrm{H}_{\mathrm{a}}: \alpha_{1} \neq 0$, maka ini berarti variabel tersebut adalah penjelas yang nyata atas variabel terikat.

Cara yang paling umum dalam melakukan uji t yaitu dengan melakukan perbandingan nilai tstatistik dengan nilai t-tabel. Sedangkan uji t dirumuskan dalam persamaan 5

$$
t=\frac{r \sqrt{n-2}}{\sqrt{1-r^{2}}}
$$

Dimana :

$$
\begin{aligned}
& \mathrm{t}=\mathrm{t} \text { hitung } \\
& \mathrm{r}=\text { Koefisien korelasi } \\
& \mathrm{n}=\text { Jumlah observasi }
\end{aligned}
$$

Jika nilai t-statistik nilainya lebih besar dari t-tabel, maka hipotesis alternatif $\left(\mathrm{H}_{\mathrm{a}}\right)$ tidak ditolak dimana memberikan informasi yaitu suatu variabel bebas sendirian memberikan mempengaruhi variabel terikat, atau apabila $\mathrm{H}_{\mathrm{o}}$ ditolak artinya muncul pengaruh signifikan dari variabel bebas atau variabel terikat.

\section{Uji Koefisien (R2)}

Pengujian ini dilakukan untuk menghitung kesanggupan model dalam menjelaskan variabel terikat dengan melaksanakan kalkulasi koefisien determinan $\left(R^{2}\right)$. Nilai kesepakatan koefisien determinan adalah berkisar antara nol(0) dan 1 (satu), atau $0<R^{2}<1$. Menurut Gujarati (2004) [20], jika $R^{2}=0$, variasi $\mathrm{Y}$ tidak dapat diterangkan oleh variasi X. Sebaliknya jika $\mathrm{R}^{2}=100 \%$, variasi $\mathrm{Y}$ dapat diterangkan oleh variasi $X$, seluruh titik observasi berada di garis regresi.

Untuk melakukan perbandingan 2(dua) $\mathrm{R}^{2}$, jumlah peubah bebas di model pendekatan mesti dikalkulasi, yakni dengan mencoba mempertimbangkan koefisien determinasi lainnya/alternatif, atau 
dikenal sebagai $\mathrm{R}^{2}$ yang dicocokkan. "dicocokkan" berarti dicocokkan pada derajat kemandirian seperti yang ditampilkan pada persamaan 6 :

$$
R^{2} \text { adjusted }=\bar{R}^{2}=1-\frac{\sum e_{t^{2}}(n-k)}{\sum y_{t^{2}}(n-1)}
$$

dimana :

$$
\begin{array}{ll}
\mathrm{n} & =\text { banyak observasi, dan } \\
\mathrm{k} & =\text { jumlah parameter yang diperkirakan dalam model. }
\end{array}
$$

\section{Hasil dan Pembahasan}

\section{Hasil Uji Normalitas}

Model regresi seharusnya juga harus dapat memenuhi asumsi clasiccal normal liniear regression model atau juga dikenal dengan uji kenormalan atau uji normalitas. Uji normalitas paling umum memakai tes Jarque-Bera $(J-B)$ Test. Suatu model diasumsikan merata normal apabila nilai kemungkinan J-B hitung $>\alpha=0,05$

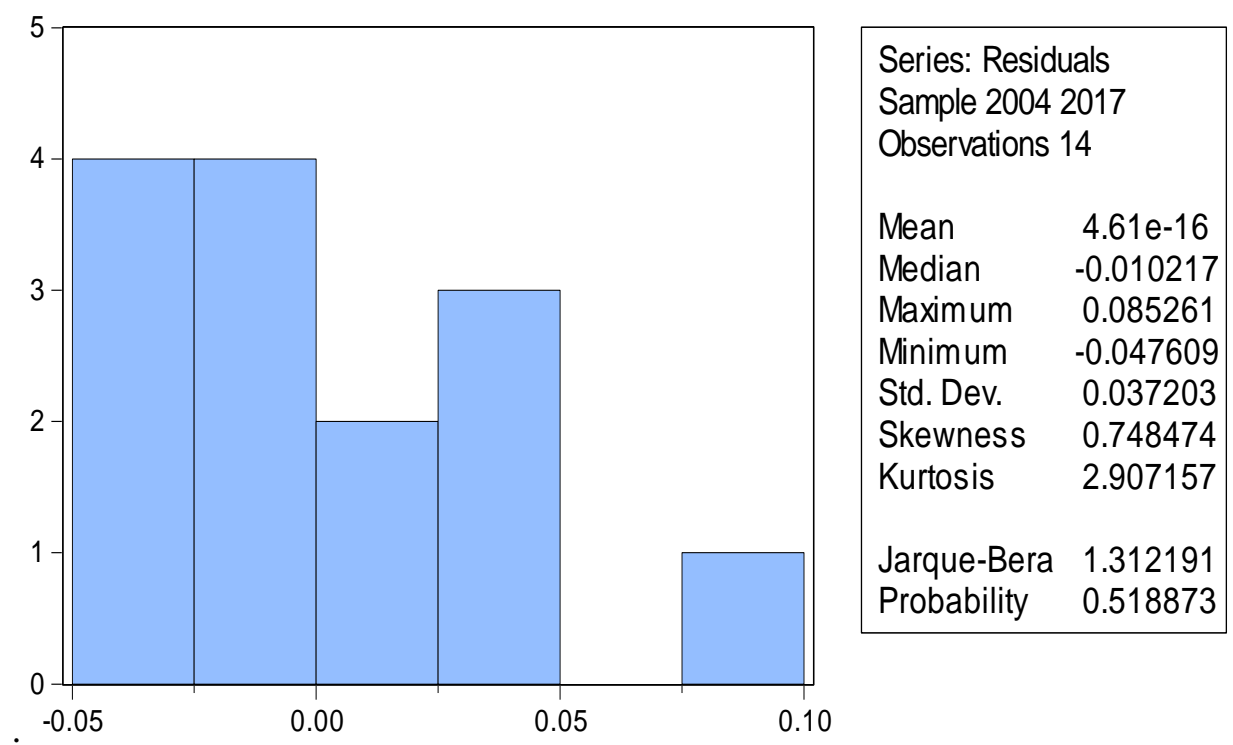

Gambar 1. Uji normalitas dengan menggunakan Jarque-Bera

Sumber: Olah data, 2019

Gambar 1 menunjukan nilai probabilitas J-B hitung untuk model Kemiskinan (POV) di kawsan Sumatera Utara adalah 1.312191 yang memiliki nilai kemungkinan $0,518873>\alpha=0,05$. Ini memberikan informasi yaitu model penelitian mempunyai data berdistribusi normal.

\section{Hasil Uji Autokorelasi}

Pengujian terhadap gejala autokorelasi dilaksanakan dengan Uji Durbin-Watson ( $D-W$ test). Model penelitian diasumsikan tidak memiliki gejala autokorelasi jika kemungkinan $O b s^{*} R$-Squared $>$ level signifikan $(\alpha=5 \%)$ atau nilai $\mathrm{Obs}^{*} R$-Squared $>$ Chi-Squared $\left(R_{(t-1)}^{2}<X_{t a b l e}^{2}\right)$. Hasil uji masalah autkorelasi yang ditunjukkan oleh nilai Durbin-Watson ( $D$-W test) ditampilkan pada Tabel 1 berikut.

Tabel 1. Hasil uji masalah autkorelasi yang ditunjukkan oleh nilai Durbin-Watson (D-W test)

\begin{tabular}{lccc}
\hline \multicolumn{1}{c}{ R-squared } & 0.945055 & Mean dependent var & 2.465201 \\
\hline Adjusted R-squared & 0.920635 & S.D. dependent var & 0.158714 \\
S.E. of regression & 0.044712 & Akaike info criterion & -3.104675 \\
Sum squared resid & 0.017993 & Schwarz criterion & -2.876440 \\
Log likelihood & 26.73272 & Hannan-Quinn criter. & -3.125802 \\
F-statistic & 38.70016 & Durbin-Watson stat & 1.554476 \\
Prob (F-statistic) & 0.000011 & & \\
\hline
\end{tabular}

Sumber: Olah data, 2019 
DW tabel pada tingkat signifikan $\alpha=0,05$, dengan banyak sampel $\mathrm{n}=14$ dan banyak variabel independen $\mathrm{k}=4$ adalah nilai $\mathrm{dL}=0,632$ dan $\mathrm{dU}=2,030$. Nilai hitung $\mathrm{DW}=1.554476$, berdomisili di sebelah dL yang memberikan informasi berada pada lokasi yang tidak dapat disimpulkan.

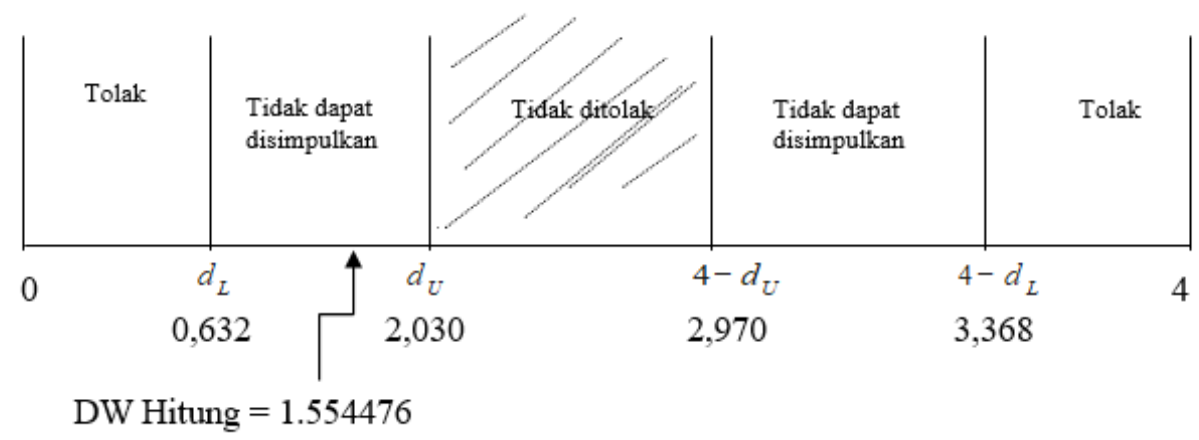

Gambar 2. hasil estimasi model nilai DW Sumber: Olah Data, 2019

Gambar 2 menampilkan hasil perkiraan model nilai DW 1.554476 dan berlokasi di daerah yang tidak dapat disimpulkan. Oleh karena itu dilakukan tes untuk memastikan model tidak mengandung problem autokorelasi selain dengan uji Durbin-Watson ( $D$-W test) yaitu uji LM. Hasil uji LM untuk model Kemiskinan di Sumatera Utara ditampilkan pada Tabel 2.

Tabel 2. Hasil Uji LM

\begin{tabular}{cccc}
\hline \multicolumn{4}{c}{ Breusch-Godfrey Serial Correlation LM Test: } \\
\hline & & & \\
F-statistic & 1.415144 & Prob. F(2,7) & 0.3047 \\
Obs*R-squared & 4.030810 & Prob. Chi-Square(2) & 0.1333
\end{tabular}

Sumber: Hasil pengolahan data, 2019

Hasil uji LM dalam Tabel 2 menjelaskan F statistic untuk model kemiskinan di Sumatera Utara adalah 1.415144 dengan kemungkinan sebesar 0.3047 , dan lebih besar dari $\alpha=0,05$ yang artinya model tidak mengandung masalah autokorelasi.

\section{Hasil Uji Multikolinearitas}

Ref [21] menyatakan bahwa sebuah model regresi dapat dinyatakan memiliki multikolinearitas jika ada relasi linier yang sempurna dalam beberapa atau seluruh variabel bebas dalam suatu model regresi. Cara mencari masalah multikolinearitas dapat dijalankan dengan dua jalan, yaitu:

1. Korelasi/hubungan antar variabel

2. Menggunakan korelasi parsial

Dalam penelitian ini uji multikolinearitas menggunakan metode korelasi antar variabel, hasil uji korelasi antar variabel dilihat pada Tabel 3.

Tabel 3. Matriks hubungan variabel bebas

\begin{tabular}{crrrr}
\hline VAR & EG & HDI & TPT & TPAK \\
\hline EG & 1.000000 & -0.626824 & 0.427514 & -0.027786 \\
HDI & -0.626824 & 1.000000 & -0.887548 & -0.216977 \\
TPT & 0.427514 & -0.887548 & 1.000000 & 0.016988 \\
TPAK & -0.027786 & -0.216977 & 0.016988 & 1.000000 \\
\hline \multicolumn{5}{c}{ Sumber : Hasil Regresi, pengolahan data (2019) }
\end{tabular}

Tabel 3 menampilkan informasi yaitu seluruh variabel mempunyai nilai $\mathrm{R}^{2}$ dibawah 0,945055 dan model dinyatakan bersih dari perkara multikolinearitas. Disamping itu juga dapat dilihat dari nilai VIF setiap variabel seperti yang ditunjukkan pada Tabel 4. 
Tabel 4. Nilai VIF Variabel Bebas

\begin{tabular}{ccccc}
\hline & EG & HDI & TPT & TPAK \\
\hline EG & 0 & 1,647198 & 1,223643 & 1,000773 \\
HDI & 1,647198 & 0 & 4,711235 & 1,049405 \\
TPT & 1,223643 & 4,711235 & 0 & 1,000289 \\
TPAK & 1,000773 & 1,049405 & 1,000289 & 0 \\
\hline \multicolumn{5}{c}{ Sumber : Hasil Regresi, pengolahan data $(2019)$}
\end{tabular}

Hasil estimasi dengan melihat nilai VIF terlihat bahwa tidak ditemukan variabel yang bernilai lebih besar dari 10 yang artinya model tidak mengandung masalah multikolinearitas. Untuk lebih memastikan model mengandung masalah multikolinearitas atau tidak nilai VIF masing-masing variabel harus dihitung.

Semakin besar nilai VIF maka perkara multikolinearitas yang semakin serius. Aturan yang dipakai adalah jika VIF > 10 dan $R_{j}^{2}>0,90$ bisa dipastikan bahwa variabel mempunyai kolinearitas tinggi.

Tabel 4 menunjukkan nilai setiap variabel bebas, yaitu : EG, HDI, TPT dan TPAK, dimana nilai VIF dari hubungan variabel-variabel independen tidak memiliki variabel dengan nilai VIF > 10. Artinya, seluruh variabel bebas yang diteliti tidak ada yang mengandung masalah kolinieritas ganda (multicollinearity).

\section{Hasil Uji F-statistik}

Nilai F-hitung sama dengan 38.70016 dengan probabilita F-statistik $<0,05$ yang berarti secara serempak variabel-variabel bebas (EG, HDI, TPT dan TPAK) berpengaruh terhadap variabel terikat persentase penduduk miskin (POV). Hasil perhitungan perkiraan telah lulus tes kecocokan model pada uji serempak, jadi hasil perkiraan bisa dipakai dalam analisis.

\section{Hasil Uji $\boldsymbol{R}^{2}$}

$\mathrm{R}^{2}$ berada pada nilai 0 dan $1 . \mathrm{R}^{2}=1$, itu memberikan informasi bahwa variabel-variabel bebas dapat memaparkan 100 persen variasi-variabel terikat. Sebaliknya, $R^{2}=0$, dimana berarti variabelvariabel bebas pada model tidak mampu menjelaskan walau sedikit ragam variabel terikat. Model diasumsikan lebih baik jika $\mathrm{R}^{2}$ mendekati angka 1 [20]. Perkiraaan model memperoleh angka $\mathrm{R}^{2}=$ 0.945055 dimana artinya, eksistensi variabel-variabel bebas (EG, HDI, TPT dan TPAK) dapat dan bisamemaparkan variabel terikat (POV) sebesar 94,51\%, diluar itu yaitu 5,49\% dipaparkan oleh variabel-variabel lain diluar model. Dengan $\mathrm{R}^{2} 0.945055$, maka hasil perkiraan telah lolos uji kesesuaian dari faktor koefisien determinasi dan hasil perkiraaan dapat dianalisis.

\section{Hasil Uji t-test}

Uji parsial juga disebut uji tingkat-penting (significance's test). Nilai t-hitung EG sama dengan 1.909598 dengan nilai kemungkinan sebesar 0.0885 lebih kecil dari $\alpha=0,10$ dimana dapat disimpulkan variabel EG signifikan mempengaruhi POV pada tingkat kesalahan sebesar $10 \%$; variabel HDI dengan nilai t statistik sebesar 1.189800 dan dengan nilai kemungkinan sebesar 0.2646 lebih besar dari $\alpha=0,10$, artinya bahwa variabel HDI tidak signifikan mempengaruhi variabel POV; variabel TPT dengan nilai $\mathrm{t}$ statstik sebesar 5.576196 dan dengan nilai kemungkinan sebesar 0.0003 lebih kecil dari $\alpha=0,10$, yang artinya bahwa variabel TPT signfikan mempengaruhi POV. Variabel TPAK dengan nilai $t$ statistik sebesar 0.267638 dan nilai kemungkinan sebesar 0.7950 lebih besar dari $\alpha=0,10$ yang artinya variabel TPAK tidak signifikan mempengaruhi POV. Hasil estimasi model kemiskinan (POV) dapat dilihat pada Tabel 5.

Tabel 5. Hasil perkiraan model kemiskinan

\begin{tabular}{ccccc}
\hline \multicolumn{4}{c}{ Dependent Variable: LOG(POV) } & \\
\hline C & Coefficient & Std. Error & t-Statistic & Prob. \\
LOG(EG) & -7.514637 & 9.404294 & -0.799064 & 0.4448 \\
LOG(HDI) & 0.202669 & 0.106132 & 1.909598 & 0.0885 \\
LOG(TPT) & 1.728060 & 1.452395 & 1.189800 & 0.2646 \\
LOG(TPAK) & 0.636673 & 0.114177 & 5.576196 & 0.0003 \\
R-squared & 0.241676 & 0.902994 & 0.267638 & 0.7950 \\
Adjusted R-squared & 0.945055 & & & \\
S.E. of regression & 0.920635 & Mean dependent var & 2.465201 \\
Sum squared resid & 0.044712 & S.D. dependent var & 0.158714 \\
& 0.017993 & Akaike info criterion & -3.104675 \\
& & Schwarz criterion & -2.876440 \\
\hline
\end{tabular}




\begin{tabular}{cccc}
\hline Log likelihood & 26.73272 & Hannan-Quinn criter. & -3.125802 \\
F-statistic & 38.70016 & Durbin-Watson stat & 1.554476 \\
Prob(F-statistic) & 0.000011 & & \\
\hline
\end{tabular}

Sumber : Keluaran Olah data dengan Eviews 7.0

Persamaan regresinya dapat dilihat pada persaman 7:

$\log (P O V)=-7,51+0,20 \log (E G)+1,73 \log (H D I)+0,64 \log (T P T)+0,24 \log (T P A K)$

Percobaan estimasi dilakukan terhadap variabel yang dianggap berpengaruh terhadap persentase penduduk miskin, seperti Pertumbuhan Ekonomi, Indeks Pembangunan Manusia, Tingkat Pengangguran Terbuka dan Tingkat Partisipasi Angkatan Kerja. Hasil estimasi yang signifikan diberikan oleh variabel Pertumbuhan Ekonomi dan Tingkat Pengangguran Terbuka.

Percobaan estimasi dilakukan terhadap variabel yang dianggap berpengaruh terhasap pesentase penduduk miskin, seperti pertumbuhan ekonomi, Indeks Pembangunan Manusia didaerah, Tingkat Tunakarya/Pengangguran Terbuka di daerah dan level Partisipasi Angkatan Kerja di daerah. Hasil estimasi yang signifikan diberikan oleh variabel Pertumbuhan Ekonomi dan Tingkat Tunakarya/Pengangguran terbuka.

\section{Pertumbuhan Ekonomi (EG)}

Hasil estimasi menunjukkan koefisien regresi pada variabel $E G=0.202669$. Dimana tiap jika ada peningkatan EG sebesar $1 \%$ maka kategori penduduk miskin (POV) akan meningkat sebanyak 0,20\%. Pengaruh variabel EG terhadap POV signifikan pada tingkat kepercayaan $90 \%$. Hasil ini tidak cocok dengan teori dan penelitian terdahulu yang mengemukakan bahwa pertumbuhan ekonomi berpengaruh secara negatif terhadap faktor kemiskinan, artinya jika pertumbuhan ekonomi naik maka kemiskinan akan menurun.

Kondisi ini sejalan dengan teori Mankiw [22], dimana disebutkan bahwa jika negara menanam modal dengan memberikan perhatian khusus pada pendidikan untuk masyarakatnya maka akan membuat pertumbuhan ekonomi menjadi lebih baik dari pada tidak, tapi penanaman modal atas sumber daya manusia melalui pendidikan akan menaikkan pendapatan nasional atau pergerakan perekonomian yang lebih tinggi. Apabila penanaman modal tersebut dilakukan lebih terdistribusi merata, termasuk di dalamnya golongan berpendapatan rendah, maka kemiskinan akan menurun

Artinya, pertumbuhan tersebut harus terdistribusi disetiap kelompok/golongan pendapatan, termasuk di kelompok penduduk kategori miskin (growth with equity). Secara langsung, ini dapat berarti bahwa pertumbuhan harus dipastikan mencapai lokasi atau bagian dimana penduduk miskin bekerja (pertanian, perkebunan atau sektor padat karya). Secara tidak langsung, diperlukan peran pemerintah yang efektif dalam meratakan pemanfaatan perkembangan yang bisa jadi diperoleh dari sektor teknologi modern seperti jasa dan pabrikasi yang padat modal.

Dalam publikasi BPS, Sumatera Utara Dalam Angka Tahun 2013-2018 menunjukkan laju pertumbuhan pada masing-masing lapangan usaha dalam perekonomian di Sumatera Utara yang dapat dilihat pada Tabel 6.

Tabel 6. Laju Pertumbuhan PDRB Atas Dasar Harga Konstan 2010 Menurut Lapangan Usaha Tahun 2014-2017 (\%)

\begin{tabular}{|c|c|c|c|c|c|}
\hline Kategori & Lapangan Usaha & 2014 & 2015 & 2016 & 2017 \\
\hline A & $\begin{array}{l}\text { Pertanian, perkebunan, Kehutanan } \\
\text { dan Perikanan }\end{array}$ & 4,37 & 5,57 & 4,65 & 5,31 \\
\hline B & Pertambangan \& Penggalian & 5,16 & 6,10 & 5,68 & 4,81 \\
\hline $\mathrm{C}$ & Industri Pengolahan & 3,00 & 3,91 & 5,05 & 2,31 \\
\hline $\mathrm{D}$ & Pengadaan Listrik dan Gas & 9,28 & 2,28 & 4,85 & 8,72 \\
\hline $\mathrm{E}$ & $\begin{array}{l}\text { Pengadaan Air, Pengelolaan Sampah, } \\
\text { Limbah dan Daur Ulang }\end{array}$ & 6,04 & 6,44 & 5,71 & 6,67 \\
\hline $\mathrm{F}$ & Konstruksi & 6,79 & 5,52 & 5,60 & 6,79 \\
\hline G & $\begin{array}{l}\text { Perdagangan usaha Besar dan Eceran, } \\
\text { Bukan Mobil dan Sepeda Motor }\end{array}$ & 6,94 & 3,91 & 5,22 & 5,87 \\
\hline $\mathrm{H}$ & Transportasi dan Pergudangan & 5,57 & 5,68 & 6,07 & 7,35 \\
\hline I & $\begin{array}{l}\text { Penyediaan Akomodasi, } \\
\text { perhotelan/penginapan dan Makan } \\
\text { Minum }\end{array}$ & 6,48 & 6,95 & 6,54 & 7,32 \\
\hline
\end{tabular}




\begin{tabular}{|c|c|c|c|c|c|}
\hline $\mathrm{J}$ & Teknologi Informasi dan Komunikasi & 7,23 & 7,11 & 7,76 & 8,57 \\
\hline K & Jasa Keuangan, BPR dan Asuransi & 2,62 & 7,17 & 4,11 & 0,49 \\
\hline $\mathrm{L}$ & Real Estate & 6,59 & 5,76 & 5,90 & 7,56 \\
\hline $\mathrm{M}, \mathrm{N}$ & Jasa Perusahaan & 6,76 & 5,86 & 5,95 & 7,46 \\
\hline $\mathrm{O}$ & $\begin{array}{l}\text { Administrasi di Pemerintahan, } \\
\text { Pertahanan dan Jaminan Sosial Wajib }\end{array}$ & 6,92 & 5,83 & 3,02 & 2,52 \\
\hline $\mathrm{P}$ & Jasa Pendidikan & 5,03 & 4,90 & 4,93 & 4,93 \\
\hline Q & Jasa Kesehatan \& Kegiatan Sosial & 6,72 & 7,21 & 7,37 & 7,64 \\
\hline $\mathrm{R}, \mathrm{S}, \mathrm{T}, \mathrm{U}$ & Jasa Lainnya & 7,04 & 6,69 & 6,50 & 7,56 \\
\hline
\end{tabular}

Sumber : BPS, 2019

Tabel 6 menunjukkan bahwa pertumbuhan terbesar lapangan usaha tahun 2017 pada perekonomian di Sumatera Utara adalah kategori (D) Pengadaan listrik dan gas selanjutnya adalah pada kategori (J) Informasi dan Komunikasi serta kategori (Q) Jasa Kesehatan dan Kegiatan Sosial. Sedangkan rata-rata pertumbuhan tertinggi selama Tahun 2013 hingga Tahun 2017 adalah pada kategori (J) Informasi dan Komunikasi, kategori (Q) Jasa Kesehatan dan Kegiatan Sosial, dan kategori (R, S, T, U) Jasa lainnya.

Lapangan usaha yang tersebut merupakan lapangan usaha yang relatif tidak banyak menyerap tenaga kerja, sementara lapangan usaha yang menyerap banyak tenaga kerja justru semakin lama semakin mengalami penurunan seperti pada kategori (C) Industri Pengolahan yang hanya mengalami pertumbuhan sebesar 2,31 \% di Tahun 2017 diikuti oleh kategori (O) Administrasi Pemerintahan, Pertahanan, dan Jaminan Sosial Wajib sebesar 2,52 \% dan kategori (B) Pertambangan dan Penggalian sebesar 4,81\%. Disamping itu lapangan usaha yang mampu menyerap tenaga terbesar pada kategori (A) Pertanian, Kehutanan dan Perikanan hanya mampu tumbuh sebesar 5,31 \% di Tahun 2017. Penyerapan tenaga kerja menurut sektor ekonomi yang datanya bersumber dari BPS (2016-2018) dapat dilihat pada Tabel 7.

Tabel 7. Tenaga kerja menurut lapangan usaha di Sumatera Utara Tahun 2015-2017

\begin{tabular}{lccc}
\hline \multicolumn{1}{c}{ Lapangan Usaha } & 2015 & 2016 & 2017 \\
\hline Pertanian, Perkebunan, Kehutanan, Perburuan dan Perikanan & 41,30 & 19,29 & 62,59 \\
Pertambangan dan Penggalian & 0,47 & 0,71 & 0,92 \\
Industri & 7,55 & 11,18 & 5,69 \\
Listrik, Gas dan Air Minum & 0,16 & 0,63 & 0,12 \\
Konstruksi & 6,03 & 7,11 & 3,77 \\
Perdagangan Besar, Rumah Makan dan Jasa Akomodasi & 21,33 & 28,55 & 12,77 \\
Transportasi, Pergudangan dan Komunikasi & 5,43 & 8,18 & 2,32 \\
Lembaga Keuangan, Usaha Persewaan Bangunan \& Jasa Perusahaan & 2,27 & 2,93 & 0,83 \\
Jasa Kemasyarakatan, Sosial dan Perorangan & 15,46 & 21,42 & 10,99 \\
\hline
\end{tabular}

Sumber : BPS, 2019

Tabel 7 menjelaskan bahwa lapangan usaha yang banyak menggunakan tenaga kerja di Provinsi Sumatera Utara adalah lapangan usaha pertanian, perkebunan, kehutanan, perburuan dan perikanan sebesar 62,59 \% di Tahun 2017 sementara laju pergerakan PDRB atas dasar harga konstan 2000 pada tahun yang sama hanya sebesar $5,31 \%$. Hal ini menunjukkan bahwa besarnya tenaga kerja di lapangan usaha tersebut tidak signifikan dalam memberikan andil pada pertumbuhan PDRB secara agregat.

Hal ini membuktikan bahwa pertumbuhan ekonomi yang tidak merata pada semua lapangan usaha tidak akan memberikan kontribusi pada penurunan kemiskinan khususnya lapangan usaha yang menyerap banyak tenaga kerja.

\section{Indeks Pembangunan Manusia (IPM)}

Hasil estimasi menunjukkan koefisien regresi variabel HDI sebesar 1.728060. Ini memberikan info bahwa tiap pertambahan HDI sebesar $1 \%$ maka penduduk miskin (POV) akan menurun sebanyak 1,73 $\%$. Pengaruh variabel HDI terhadap POV tidak nyata/signifikan pada level kepercayaan $90 \%$.

Hasil ini tidak sesuai dengan teori dan riset terdahulu yang mengemukakan bahwa IPM berpengaruh negatif atas kemiskinan, dimana jika IPM bertambah maka kemiskinan akan berkurang.

Kondisi ini dapat dijelaskan dimana IPM yang merupakan Indeks Komposit yang terbentuk dari indeks pendidikan masyarakat, indeks kesehatan masyarakat dan indeks kemampuan daya beli masyarakat. Dari ketiga indeks tersebut hanya 1 indeks yang terkait langsung dengan kemiskinan yaitu kemampuan daya beli sedangkan kedua indeks lainnya meskipun berpengaruh terhadap kemiskinan namun tidak secara langsung.

Artinya, kemiskinan yang terjadi di Provinsi Sumatera Utara terkait dengan kurangnya daya beli penduduk untuk pemenuhan kebutuhan pokok pangan. Peningatan kemampuan daya beli penduduk 
terhadap kebutuhan pokok pangan akan menaikkan kualitas sumber daya manusia yang akan berefek langsung atas kinerja dan meningkatkan pendapatan pada akhirnya.

\section{Tingkat Pengangguran Terbuka (TPT)}

Hasil estimasi menunjukkan koefisien regresi variabel TPT sebesar 0.636673. Dimana tiap pertambahan TPT sebesar $1 \%$, penduduk miskin (POV) akan naik sebanyak 0,64 \%. Pengaruh variabel TPT terhadap POV signifikan pada tingkat kepercayaan $90 \%$. Benar adanya yaitu jika tingkat pengangguran tinggi maka masyarakat miskin akan tinggi juga.

Hasil penelitian ini sesuai dengan Ref.[9] yang menyatakan bahwa ada hubungan yang erat sekali antara tingginya tingkat pengangguran dan kemiskinan. Bagi sebagian besar masyarakat, yang tidak mempunyai pekerjaan tetap atau hanya part-time selalu berada diantara kelompok masyarakat yang sangat miskin.

Penelitian yang sama ditunjukkan oleh Ref. [23], dimana hasilnya adalah variabel pengangguran memberikan berpengaruh positif atas kemiskinan, hasil penelitian Ref. [24] menampilkan yaitu variabel pengangguran berpengaruh positif atas tingkat kemiskinan. Menurut Ref. [3] memberikan hasil bahwa variabel pengangguran meberikan pengaruh positif dan nyata/signifikan atas penduduk miskin.

\section{Tingkat Partisipasi Angkatan Kerja (TPAK)}

Hasil estimasi menunjukkan koefisien regresi variabel TPAK $=0.241676$. Dimana tiap penambahan TPAK sebesar $1 \%$ maka penduduk miskin (POV) akan meningkat sebanyak 0,24\%. Pengaruh variabel TPAK terhadap POV tidak signifikan pada tingkat kepercayaan $90 \%$.

\section{Kesimpulan}

Variabel Pertumbuhan Ekonomi (EG) berpengaruh positif dan signifikan terhadap Kemiskinan (POV) yang berarti jika Pertumbuhan Ekonomi (EG) meningkat maka Kemiskinan (POV) akan meningkat di Provinsi Sumatera Utara. Variabel Indeks Pembangunan Manusia (IPM/HDI) berpengaruh negatif dan tidak signifikan terhadap Kemiskinan (POV) yang berarti jika Indeks Pembangunan Manusia (IPM/HDI) meningkat maka Kemiskinan (POV) akan menurun di Provinsi Sumatera Utara. Variabel Tingkat Pengangguran Terbuka (TPT) berpengaruh positif dan signifikan terhadap Kemiskinan (POV) yang berarti jika Tingkat Pengangguran Terbuka (TPT) meningkat maka Kemiskinan (POV) akan meningkat di Provinsi Sumatera Utara. Variabel Tingkat Partisipasi Angkatan Kerja (TPAK) berpengaruh positif dan tidak signifikan terhadap Kemiskinan (POV) yang berarti jika Tingkat Partisipasi Angkatan Kerja (TPAK) meningkat maka Kemiskinan (POV) akan meningkat di Provinsi Sumatera Utara.

\section{Daftar Pustaka}

[1] Zulfan, "Dampak Pengembangan Kawasan Pelabuhan Kuala Langsa Terhadap Kesejahteraan Masyarakat Sekitar," Universitas Sumatera Utara, 2008.

[2] I. Maipita, Memahami dan Mengukur Kemiskinan. Yogyakarta: Absolue Media, 2013.

[3] R. D. Wijayanto, "Analisis Pengaruh Pdrb, Pendidikan Dan Pengangguran Terhadap Kemiskinan Di Kabupaten / Kota Jawa Tengah Tahun 2005 - 2008," Universitas Diponegoro, 2010.

[4] A. M. Balisacan, E. M. Pernia, and A. Asra, "Revisiting growth and poverty reduction in Indonesia: What do subnational data show?," ERD Work. Pap. Ser., 2002.

[5] G. Ranis and F. Stewart, "Economic growth and human development in Latin America," 2002.

[6] H. Siregar, "Perbaikan Struktur dan Pertumbuhan Ekonomi: Mendorong Investasi dan Menciptakan Lapangan Kerja,” J. Ekon. Polit. dan Keuang., 2006.

[7] S. Hadi, "Dampak Investasi Sumberdaya Manusia Terhadap Pertumbuhan Ekonomi dan Kemiskinan di Provinsi Papua Barat: Pendekatan Model Computable General Equilibrium," Agrotek, 2018, doi: 10.30862/agt.v2i4.502.

[8] Sadono Sukirno, Teori Pengantar Makroekonomi. 2016.

[9] L. Arsyad, Ekonomi pembangunan. Yogyakarta: STIE YKPN, 1997.

[10] Sugiyono, Metodologi Penelitian dan Pengembangan. Bandung. 2016.

[11] J. M. Mustafa, Sirojuzilam, and N. Sulistiyono, "Analisis Tingkat Kerawanan Longsor Dengan Integrasi Analytical Hierarchy Process dan Pemodelan Spasial Sistem Informasi Geografis di Kabupaten Aceh Tenggara," Serambi Eng., vol. 4, no. Khusus, pp. 471-481, 2019.

[12] A. Dajan, Pengantar Metode Statistik Jilid II. 1986.

[13] Sugiyono, "Metode Penelitian Bisnis (Pendekatan Kuantitatif, kualitatif, dan R\&D)," Alfabeta. 2017, doi: 10.1017/CBO9781107415324.004.

[14] B. P. Statistik, "Sumatera Utara dalam angka.", 2019 
[15] J. Harefa, Zulkifli, and A. S. Toha, "Analisis Daerah Rawan Bencana Tsunami Terhadap Pemanfaatan Lahan Perumahan dan Permukiman Kota Gunungsitoli Berbasis Geospasial," Serambi Eng., vol. 5, no. 1 Januari 2020, pp. 824-834, 2020.

[16] E. Widodo, E. Suriani, I. P. Ristyaningrum, and G. E. Kusumandari, "Analisis Regresi Panel pada Kasus Kemiskinan di Indonesia," in PRISMA, Prosiding Seminar Nasional Matematika, 2019.

[17] L. U. H. PRATIWI, I. G. A. Srinadi, and M. Susilawati, "Analisis Kemiskinan Dengan Pendekatan Model Regresi Spasial Durbin (Studi Kasus: Kabupaten Gianyar),' E-Jurnal Mat., vol. 2, p. 11, 2013, doi: 10.24843/MTK.2013.v02.i03.p042.

[18] Irhamni, S. Pandia, E. Purba, and W. Hasan, "Pengaruh Konsentrasi Leachate Terhadap Pertumbuhan Tanaman Uji," Serambi Eng., vol. V, no. 1, pp. 808-815, 2020.

[19] Norizan Esa, Nordin Abd. Razak, and Mohd. Ali Samsuddin, Analisis Data Kuantitatif. Jakarta: Gramedia, 2013.

[20] Damodar N Gujarati, Dasar-Dasar Ekonometrika Buku 2 Edisi 5. Salemba Empat, 2012.

[21] L. I. Smith, "A tutorial on Principal Components Analysis Introduction," Statistics (Ber)., 2002.

[22] N. G. Mankiw, D. Romer, and D. N. Weil, "A Contribution to the Empirics of Economic Growth," Q. J. Econ., 1992, doi: 10.2307/2118477.

[23] D. T. Amijaya, "Pengaruh ketidakmerataan distribusi pendapatan, pertumbuhan ekonomi, dan pengangguran terhadap tingkat kemiskinan di Indonesia tahun 2003-2004," 2008.

[24] A. A. Prastyo, "Analisis Faktor-Faktor Yang Mempengaruhi Tingkat Kemiskinan (Studi Kasus 35 Kabupaten/Kota Di Jawa Tengah Tahun 2003-2007,” Universitas Dipenogoro, 2010. 